\title{
The Use of MOOCS in Online Engineering Education
}

\author{
https://doi.org/10.3991/ijep.v11i3.20411 \\ Marina Zotova \\ Moscow City Pedagogical University, Moscow, Russia \\ Tetiana Likhouzova $\left({ }^{\square}\right)$ \\ Moscow City Pedagogical University, Moscow, Russia \\ Igor Sikorsky Kya Polytechnique Institute, Kyiv, Ukraine \\ likhouzovatet55erambler.ru \\ Liliya Shegai \\ Far Eastern Federal University, Vladivostok, Russia \\ Elena Korobeynikova \\ Saint-Petersburg University of State Fire Service of EMERCOM of Russia, \\ Saint-Petersburg, Russia
}

\begin{abstract}
The study demonstrates the possibilities of using massive open online courses in engineering education. In order to study the impact of digital learning formats on the acquisition of key engineering competencies by students, an educational experiment was carried out; it was performed as part of the study of the Fire Safety discipline on the basis of the online educational platform Khan Academy. Conceptually, the educational process was aimed at studying the capabilities of software in the field of fire safety, namely: PyroSim, Pathfinder, FireRisk, FIM, FireCategories, PromRisk, FireDistance, as well as gaining professional competencies in the process of performing practical tasks. The educational experiment involved third-year intramural and extramural students of the Faculty of Engineering (The Saint-Petersburg University of the State Fire Service of the EMERCOM of Russia) and Moscow City Pedagogical University. The online educational course was conducted with an emphasis on consolidation and acquisition of professional engineering knowledge and skills in the development of fire safety projects under simulated risk conditions using modern software and an innovative educational platform. The participants demonstrated a high level of involvement, initiative and professional aspirations in the learning process. In the context of the educational experiment, the key competencies required for 21 st century engineers have been identified. The students confirmed the positive impact of digital pedagogical tools on the acquisition and development of key competencies necessary for further professional activity. Having completed an online course on the Khan Academy platform focused on the applied interaction with advanced software in the field of fire safety, students identified skills that should be developed and consolidated, namely: teamwork skills and the ability to work in multidisciplinary teams, the ability to manage projects (management, planning, scheduling, budgeting, etc.); the ability to define, formulate and solve engineering problems; the ability to effectively prioritize; striving for lifelong learning; willingness to take a calculated risk;
\end{abstract}


ability to make professional decisions; self-regulation and self-motivation. However, the development of important engineering competencies such as high ethical standards, honesty and global social, intellectual and technological responsibility; good communication skills, high emotional intelligence and cognitive flexibility; entrepreneurial spirit and customer focus requires educators to search for different pedagogical methods and practices. The assessment of the impact of digital learning formats on the acquisition of key engineering competencies was subjective, but revealed pedagogical approaches to the qualitative development of engineering personnel. An effective combination of traditional classroom and virtual interactions can create a complex paradigm of highquality engineering and technical education that is competitive in the market environment.

Keywords - Digital educational platforms; engineering education; massive open online courses (MOOCs); online learning; professional competencies

\section{Introduction}

Information and communication technologies are becoming an increasingly important part of student learning as the advent of Web 2.0 technologies has allowed the creation of educational content that is no longer based on traditional textbooks, and the classroom now involves the use of both physical and virtual space. A important educational trend has been the introduction of so-called learning management systems, which are used as a common platform on which students and teachers can interact digitally [1]. In the field of engineering education, information and communication technologies are constantly improving teaching methods. Technological advances have changed the views on engineering education [2]. E-learning can further expand engineering education through the use of electronic sources, online courses, blended learning, lecture management systems, and other communication and collaboration tools [3].

E-learning caters to the needs of today's students based on their own requirements and preferences. The concept of e-learning is an innovative teaching method that depends on the latest mathematical technologies, a global network of information and multimedia, dialogue fields, discussions and virtual classrooms. The main advantages of e-learning include: easy access to the teacher and educational content; opportunities for effective communication in the learning environment; promoting the formation of different views of students; the possibility of modeling approaches to training; adaptability of different teaching methods; simplicity and many ways to assess the development of a student [4].

The learning experience of students in an e-learning environment is different from that in a face-to-face learning environment. Student orientation, independence, interactivity, flexibility seen as advantages of this environment, which provides opportunities for continuous and effective learning [5].

Massive open online courses (MOOCs) have penetrated in higher education shaping new styles and methods of pedagogy. MOOCs are online courses designed for 
open and unrestricted education on the Internet [6]. Advanced web technologies allow massive open online courses to transform and create high quality educational courses. MOOCs are a relatively new technology that has not yet been "normalized" in everyday educational practice. Basically, research on this technology is focused on the use of MOOCs as part of a broader approach to education [7].

The evolution of digital media has created new opportunities for people of all ages seeking high-quality education. In 2012 there was an important turning point - the year saw a boom in the popularity of Massive Open Online Courses (MOOCs) around the world [8]. Universities are rather successfully integrating MOOCs into traditional curricula to support different learning preferences, introduce students to the technological capabilities of innovative teaching methods, and make learning more accessible and inclusive. In addition, there is a growing interest in exploring the possibilities of MOOCs to enrich traditionally taught courses and become an additional resource to help teachers and students achieve their goals in a blended learning format [9]. The use of MOOCs gives students access to additional educational content and a personalized learning environment [10] allowing them to study and model educational content, develop key skills, socially interact with the teacher and fellow students. MOOCs support student experience in a virtual environment by providing learners with new learning experiences that prioritize the ability to learn at their own pace, forge group partnerships, and join forces to deliver a project. Learning activities are a real alternative to teamwork, which is an integral part of engineering learning, where students must solve real-world problems individually and in collaboration. In addition, peer support is critical to obtaining successful learning outcomes [11].

MOOCs offer unlimited opportunities for students who take responsibility for their own learning while focusing on new teaching styles and technological developments [12]. MOOCs provide an opportunity to work, test, investigate and consolidate informal learning [13]. Informal learning can make a significant contribution in engineering education by helping students or staff interact with peers and more experienced colleagues, exchange ideas and discuss engineering problems [14]. Meaningful learning in engineering is achieved through effective interactions in online groups. The proliferation of technological tools in teaching and learning has created new opportunities to support collaborative learning in a distance format [15]. Collaborative learning refers to educational approaches that encourage learners to work together to find a common solution to a given problem. Collaborative learning involves the efforts of students who mutually seek meaning, understanding, or solutions through negotiations [16]. Collaboration encourages information exchange, knowledge acquisition, and skill development [17]. Therefore, a well-structured course with an emphasis on group work can ensure effective student interaction in the context of distance learning in a digital environment [18].

The purpose of the research is to investigate the possibilities of using massive open online courses in engineering education in a digital environment. 
To achieve this goal, the following tasks have been set:

- To deliver a distance learning course as part of the study of the Fire safety discipline on the basis of the educational online platform Khan Academy involving third-year intramural and extramural students of The Saint-Petersburg University of the State Fire Service of the EMERCOM of Russia and Moscow City Pedagogical University.

- To place an emphasis on consolidating and gaining professional engineering knowledge and skills in the development of fire safety projects under simulated risk conditions using modern software (PyroSim, Pathfinder, FireRisk, FIM, FireCategories, PromRisk, FireDistance) and innovative educational tools.

- In the context of the educational experiment, to determine the key competencies that engineers of the 21 st century should have.

- To assess the impact of digital pedagogical tools on the acquisition and development of key competencies that fire safety engineers need to conduct professional activities.

- To identify pedagogical approaches to the quality development of engineering personnel.

\section{Research Methodology}

Open educational resources are freely accessible online materials that reside in the public domain. These materials include online courses, video tutorials, textbooks and other digital resources that support access to knowledge. In recent years, millions of Internet users have attended online classes offered by the Massive Open Online Course (MOOC) platforms [19].

Massive Open Online Courses (MOOCs) have entered the educational ecosystem, attracting the attention of government media, businesses, teachers and students, contributing to the wider diffusion and democratization of education around the world. MOOCs have proven to be an effective tool in aspects of open online education [20]. Table 1 shows the world popular MOOC providers. 
Table 1. Largest MOOC Providers

\begin{tabular}{|c|c|c|c|}
\hline Providers & Verdict & Pros & Cons \\
\hline Udacity & $\begin{array}{l}\text { One of the best online } \\
\text { learning platforms with } \\
\text { some good quality courses }\end{array}$ & $\begin{array}{l}\text { Simplistic design (no unnecessary infor- } \\
\text { mation) } \\
\text { High-quality courses (even the free ones) } \\
\text { Variety of features }\end{array}$ & $\begin{array}{l}\text { Price spike } \\
\text { Lack of customer } \\
\text { support (in some } \\
\text { cases) } \\
\text { Lack of a community }\end{array}$ \\
\hline edX & $\begin{array}{l}\text { Offers University-level } \\
\text { online courses. }\end{array}$ & $\begin{array}{l}\text { Well-established in the industry } \\
\text { A wide range of features to choose from } \\
\text { University-level courses } \\
\text { Easy to navigate }\end{array}$ & $\begin{array}{l}\text { Some courses are too } \\
\text { expensive } \\
\text { The platform is } \\
\text { unstable at times }\end{array}$ \\
\hline Udemy & $\begin{array}{l}\text { Online learning platform for } \\
\text { different needs. }\end{array}$ & $\begin{array}{l}\text { Huge variety of courses } \\
\text { Easy to navigate } \\
\text { No technical issues } \\
\text { Seems to care about its users }\end{array}$ & $\begin{array}{l}\text { Pricing can be con- } \\
\text { fusing } \\
\text { A bit dry in the } \\
\text { feedback department }\end{array}$ \\
\hline Coursera & $\begin{array}{l}\text { The platform offers multiple } \\
\text { unique features. }\end{array}$ & $\begin{array}{l}\text { Professional service } \\
\text { Flexible timetables } \\
\text { A variety of features to choose from } \\
\text { You can get a degree }\end{array}$ & $\begin{array}{l}\text { Expensive } \\
\text { Courses could be a } \\
\text { bit difficult for } \\
\text { absolute beginners }\end{array}$ \\
\hline DataCamp & $\begin{array}{l}\text { Multiple courses on data } \\
\text { science offered }\end{array}$ & $\begin{array}{l}\text { Easy to use } \\
\text { Offers quality content } \\
\text { Very transparent with their pricing } \\
\text { The price matches the quality } \\
\text { Beginner-friendly }\end{array}$ & $\begin{array}{l}\text { Free users get a } \\
\text { relatively small } \\
\text { amount of courses } \\
\text { and other content }\end{array}$ \\
\hline $\begin{array}{l}\text { Khan } \\
\text { Academy }\end{array}$ & $\begin{array}{l}\text { A free-to-use, math-oriented } \\
\text { online learning platform. }\end{array}$ & $\begin{array}{l}100 \% \text { free } \\
\text { Good and reputable content } \\
\text { A wide variety of courses to choose from } \\
\text { No ads }\end{array}$ & $\begin{array}{l}\text { Could have more } \\
\text { courses on certain } \\
\text { specific topics }\end{array}$ \\
\hline LinkedIn & $\begin{array}{l}\text { A good online learning } \\
\text { platform, especially for } \\
\text { beginners in some specific } \\
\text { fields. }\end{array}$ & $\begin{array}{l}\text { Professionally made } \\
\text { Easy to use } \\
\text { Nice features }\end{array}$ & $\begin{array}{l}\text { No accredited certifi- } \\
\text { cation } \\
\text { No pricing options } \\
\text { (only a monthly and } \\
\text { an annual plans) } \\
\text { Lack of specific } \\
\text { course difficulties } \\
\text { (not enough ad- } \\
\text { vanced level courses) }\end{array}$ \\
\hline Skillshare & $\begin{array}{l}\text { One of the leading online } \\
\text { learning platforms. }\end{array}$ & $\begin{array}{l}\text { User-friendly interface } \\
\text { Straightforward interface } \\
\text { Plenty of courses to choose from } \\
\text { Unique features }\end{array}$ & $\begin{array}{l}\text { Pricing problems } \\
\text { The video player } \\
\text { could be better } \\
\text { (bothersome com- } \\
\text { ments / timestamps) }\end{array}$ \\
\hline
\end{tabular}

* Developed on the basis of [21]

The global MOOC market is projected to demonstrate an annual growth rate of $29 \%$ from 2020 to 2025 that will make it the fastest growing education market. This means that the size of the global MOOC market could reach $\$ 21.4$ billion by 2025 , as the market was valued at $\$ 5.16$ billion in 2019 [22]. About 59\% of the American elearning market share comes from by online learning products [23]; more than $30 \%$ of American students are enrolled in at least one online course [24]; 52\% of postgraduates in the United States believe that their online education has provided a better learning experience than traditional classroom instruction [25]. The e-learning market in the European Union is led by Germany [26]. The German online learning market 
annual growth rate is $8.5 \%$. According to the European Association of Universities Report, the main mission of the European Higher Education Area is to use digital learning to improve traditional higher education rather than replace it [27].

Innovative online technologies are bringing changes to the global education system by transforming the teaching and learning paradigm. In the context of new admission policies of higher educational institutions, online learning can become a tool to encourage students to continue their studies. Online courses have gained popularity in recent years; thus, students are more likely to take advantage of the opportunity to do an online course [28].

STEM (Science, Technology, Engineering and Mathematics) has become a popular term in education around the world. Recognized that there is a need for a workforce with adequate STEM knowledge and skills to meet the challenges of the future. While STEM education has attracted increased attention from researchers and practitioners, also filled with debate and dilemmas. There is no consensus on what STEM education means and how it had put into practice. In a broad sense, this refer either to the sum of the individual disciplines involved in STEM, or to an interdisciplinary approach to STEM education that emphasizes links between disciplines [29]. Engineering designdriven technology learning activities enhance STEM learning. Applying the engineering design process to STEM-based teaching is useful for developing design-thinking patterns, especially with regard to problem clarification, idea generation, modeling, and feasibility studies. It is important to encourage students to further explore the systematic concepts of engineering design thinking and expand capabilities by integrating the engineering design process with STEM project-based learning [30].

\section{$3 \quad$ Research Design}

The educational experiment was performed as part of the study of the Fire Safety discipline on the basis of the online educational platform Khan Academy in 2020. Conceptually, the educational process was aimed at studying the capabilities of software in the field of fire safety, namely: PyroSim, Pathfinder, FireRisk, FIM, FireCategories, PromRisk, FireDistance, as well as gaining professional competencies in the process of completing practical tasks. The course complimented the Fire Safety curriculum emphasizing practical independent work of students.

It was focused on the consolidation and acquisition of professional engineering knowledge and skills in the development of fire safety projects under simulated risk conditions using modern software and an innovative educational platform. The duration of the online course was 6 months. It consisted of video lessons, practical assignments, group interactions, and teacher feedback (Table 2). 
Table 2. Fire safety software included in the educational course

\begin{tabular}{|c|c|c|}
\hline Software & Description & Capabilities \\
\hline $\begin{array}{l}\text { PyroSim (fire } \\
\text { simulation } \\
\text { model) }\end{array}$ & $\begin{array}{l}\text { A graphical user interface for the } \\
\text { FDS that allows quickly and } \\
\text { easily creating, editing and } \\
\text { analyzing complex fire patterns. }\end{array}$ & $\begin{array}{l}\text {-Calculation of the time of blocking evacuation routes; } \\
\text {-Import of CAD models; } \\
\text {-Parallel calculations; } \\
\text {-HVAC system; } \\
\text {-Library of properties for various objects; } \\
\text {-Interactive editing of objects; } \\
\text {-Visualization of calculation results. }\end{array}$ \\
\hline $\begin{array}{l}\text { Pathfinder } \\
\text { (calculation of } \\
\text { emergency } \\
\text { evacuation } \\
\text { time) }\end{array}$ & $\begin{array}{l}\text { Emergency evacuation simula- } \\
\text { tion software with rescue capa- } \\
\text { bility includes a graphical user } \\
\text { interface for model creation and } \\
\text { a module for viewing animated } \\
\text { 3D results. }\end{array}$ & $\begin{array}{l}\text {-Calculation of the evacuation time; } \\
\text {-Modeling the rescue of immobile people; } \\
\text {-Visualization of fire hazards along with the evacuation of } \\
\text { people; } \\
\text {-Human flow density; } \\
\text {-Ample import opportunities; } \\
\text {-Movement mesh model; } \\
\text {-Combination of parameters for choosing the path to the } \\
\text { exit; } \\
\text {-High quality three-dimensional visualization; } \\
\text {-The use of elevators, stairs, escalators, moving walkways } \\
\text { and ramps when simulating evacuation; } \\
\text {-Turnstiles and other flow restrictions; } \\
\text {-Analysis of evacuation results. }\end{array}$ \\
\hline $\begin{array}{l}\text { FireRisk } \\
\text { (calculation of } \\
\text { fire risk) }\end{array}$ & $\begin{array}{l}\text { The software interface allows } \\
\text { quickly and clearly setting } \\
\text { coefficients to calculate an } \\
\text { individual fire risk and analyze } \\
\text { the results. }\end{array}$ & $\begin{array}{l}\text {-PyroSim data processing; } \\
\text {-Pathfinder data processing; } \\
\text {-Graphs of fire hazards and movements of people; } \\
\text {-Areas of increased fire risk; } \\
\text {-Report. }\end{array}$ \\
\hline $\begin{array}{l}\text { FIM (fire } \\
\text { integral mod- } \\
\text { el) }\end{array}$ & $\begin{array}{l}\text { The FIM software allows users } \\
\text { to perform calculations in } \\
\text { IntModel (integral model) and } \\
\text { CFAST (zone model) using the } \\
\text { input file of the FDS format as } \\
\text { the initial data. }\end{array}$ & $\begin{array}{l}\text {-Calculations in the integral and zone models; } \\
\text {-Series of estimated calculations, consideration of the } \\
\text { most dangerous scenarios before the final calculation in } \\
\text { the field model; } \\
\text {-Series of calculations to assess various options for space- } \\
\text { planning solutions, parameters of the fire-fighting sys- } \\
\text { tems, etc. } \\
\text {-Calculations of smoke exhaust in CFAST. }\end{array}$ \\
\hline $\begin{array}{l}\text { FireCategories } \\
\text { (calculation of } \\
\text { categories) }\end{array}$ & $\begin{array}{l}\text { The FireCategories software is } \\
\text { designed to determine the cate- } \\
\text { gories of premises, buildings and } \\
\text { outdoor installations in terms of } \\
\text { explosion and fire hazard. }\end{array}$ & $\begin{array}{l}\text {-Plotting dependency diagrams of blast overpressure; } \\
\text {-Refinement of all stages of the calculation; } \\
\text {-Database of substances and materials; } \\
\text {-Report. }\end{array}$ \\
\hline $\begin{array}{l}\text { PromRisk } \\
\text { (risk calcula- } \\
\text { tion at produc- } \\
\text { tion facilities) }\end{array}$ & $\begin{array}{l}\text { The software for calculating } \\
\text { individual and social fire risk at } \\
\text { production facilities. }\end{array}$ & $\begin{array}{l}\text {-Building a model for calculation; } \\
\text {-Simulation of spills of flammable liquids; } \\
\text {-Event tree; } \\
\text {-Areas of fire hazards, probability of death and risk; } \\
\text {-Fire hazard graphs; } \\
\text { - report. }\end{array}$ \\
\hline $\begin{array}{l}\text { FireDistance } \\
\text { (determination } \\
\text { of a safe } \\
\text { distance) }\end{array}$ & $\begin{array}{l}\text { The FireDistance software is } \\
\text { designed to determine a safe } \\
\text { distance between buildings. }\end{array}$ & $\begin{array}{l}\text {-User-friendly and intuitive interface; } \\
\text {-Plotting the heat flow in case of fire in all buildings; } \\
\text {-Determination of the minimum permissible distance } \\
\text { between the calculated one and each of the neighboring } \\
\text { buildings; } \\
\text {-Detailed report. }\end{array}$ \\
\hline
\end{tabular}

*Own development based on [31] 
A comprehensive educational product "Fire Safety" was offered to students on the Khan Academy online platform using educational video lessons and demo versions offered by the software developers.

KhanAcademy offers practical tasks, instructional videos, and a personalized learning dashboard that empowers learners to organize the learning process at their own pace in classroom or online format [32].

The educational experiment involved third-year intramural and extramural students of Moscow City Pedagogical University and the Faculty of Engineering (The SaintPetersburg University of the State Fire Service of the EMERCOM of Russia) studying in the following specialties: 20.05.01 "Fire safety"; 20.03.01 "Technosphere safety" (specialization: "Management of high-risk rescue operations"); 20.03 .01 "Technosphere safety" (specialization: "Fire safety") (Table 3).

Table 3. Participants in the educational experiment

\begin{tabular}{|c|l|l|}
\hline $\begin{array}{c}\text { Number of students } \\
\text { in the group }\end{array}$ & \multicolumn{1}{|c|}{ Specialty } & Mode of attendance \\
\hline 42 & 20.05 .01 "Fire safety" & $\begin{array}{l}\text { Intramural - 27 } \\
\text { Extramural - 15 }\end{array}$ \\
\hline 45 & $\begin{array}{l}20.03 .01 \text { "Technosphere safety" (specialization: "Manage- } \\
\text { ment of high-risk rescue operations"); }\end{array}$ & Extramural - 45 \\
\hline 38 & $\begin{array}{l}20.03 .01 \text { "Technosphere safety" (specialization: "Fire } \\
\text { safety") }\end{array}$ & $\begin{array}{l}\text { Intramural - 23 } \\
\text { Extramural - 15 }\end{array}$ \\
\hline Total: 125 & \multicolumn{1}{|c|}{$\begin{array}{l}\text { Total: Intramural - 50 } \\
\text { Extramural - 75 }\end{array}$} \\
\hline
\end{tabular}

*Own development based on [34,35]

\section{$4 \quad$ Results}

A review of recent publications discussing the need for a new paradigm in education, and in particular in STEM education, provides some guidance on what needs to be changed [33]. In 2015, the World Economic Forum published a report on the pressing challenge of the 21st-century skills gap and ways to address it through technology [34]. The report identified a set of 16 critical skills needed in the 21 st century, which were grouped into three categories: basic literacy, competencies, and character traits. The American Society for Engineering Education (ASEE) supported by the National Science Foundation (NSF) is involved in a multi-year effort to identify the knowledge, skills, and abilities (KSA) of rising engineers. Transforming Undergraduate Education in Engineering (TUEE) clearly defines the need to transform approaches to engineering education and describes skills that the coming generation of engineers will need [35]. The competencies that 21 st-century engineers should possess are shown in Fig. 1. 


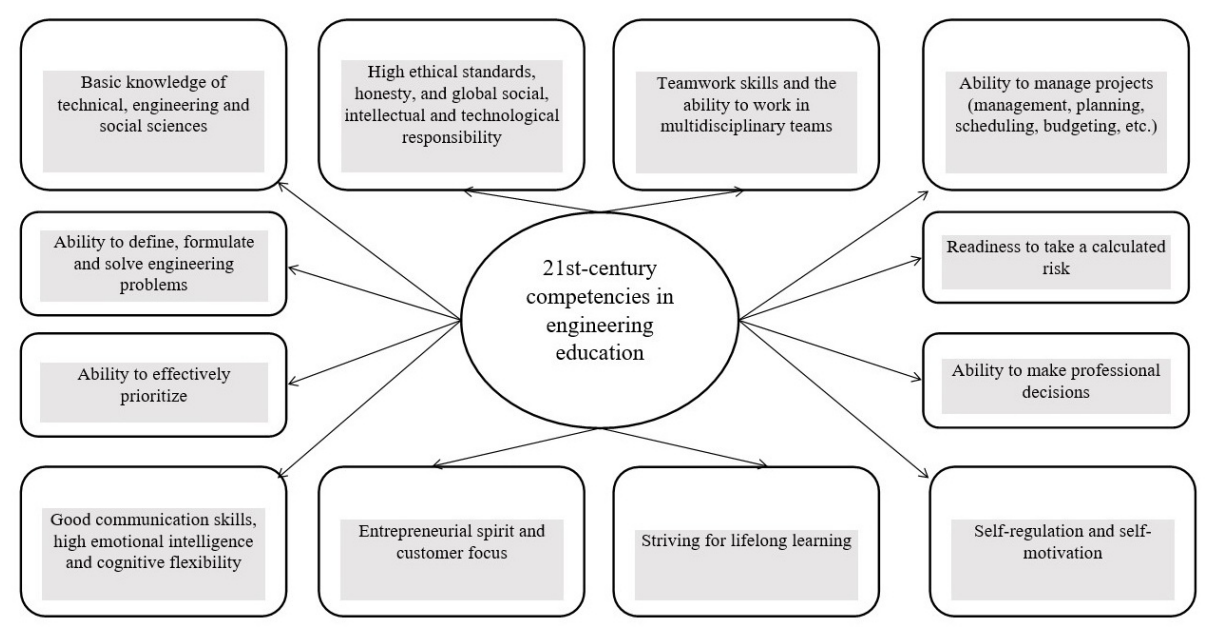

Fig. 1. Competencies of a 21st-century engineer

After the course was finished, a survey aimed at studying the impact of distance learning formats on the development of key professional competencies was conducted. The survey results are described below (Table 4).

Table 4. Assessment of the impact of digital learning formats on the acquisition of key competencies of a modern engineer

\begin{tabular}{|c|c|c|c|c|c|}
\hline \multirow{3}{*}{ No. } & \multirow{3}{*}{ Professional competencies } & \multicolumn{4}{|c|}{$\begin{array}{c}\text { Subjective assessment of the impact } \\
(\%)\end{array}$} \\
\hline & & \multicolumn{4}{|c|}{$N=125$} \\
\hline & & No impact & $\begin{array}{l}\text { Partial } \\
\text { impact }\end{array}$ & $\begin{array}{l}\text { Some } \\
\text { impact }\end{array}$ & $\begin{array}{l}\text { Serious } \\
\text { impact }\end{array}$ \\
\hline 1 & $\begin{array}{l}\text { Basic knowledge of technical, engineering and social scienc- } \\
\text { es }\end{array}$ & & & 31 & 69 \\
\hline 2 & $\begin{array}{l}\text { High ethical standards, honesty, and global social, intellectu- } \\
\text { al and technological responsibility }\end{array}$ & 10 & 13 & 21 & 56 \\
\hline 3 & $\begin{array}{l}\text { Teamwork skills and the ability to work in multidisciplinary } \\
\text { teams }\end{array}$ & & & 18 & 82 \\
\hline 4 & $\begin{array}{l}\text { Ability to manage projects (management, planning, schedul- } \\
\text { ing, budgeting, etc.) }\end{array}$ & & & 3 & 97 \\
\hline 5 & Ability to define, formulate and solve engineering problems & & & 9 & 91 \\
\hline 6 & Ability to effectively prioritize & & & 21 & 79 \\
\hline 7 & $\begin{array}{l}\text { Good communication skills, high emotional intelligence and } \\
\text { cognitive flexibility }\end{array}$ & 31 & 43 & 19 & 7 \\
\hline 8 & Entrepreneurial spirit and customer focus & 18 & 26 & 19 & 37 \\
\hline 9 & Striving for lifelong learning & & & 7 & 93 \\
\hline 10 & Readiness to take a calculated risk & & 5 & 20 & 75 \\
\hline 11 & Ability to make professional decisions & & 6 & 11 & 83 \\
\hline 12 & Self-regulation and self-motivation & & & 10 & 90 \\
\hline & Average & 4.92 & 7.75 & 15.75 & 71.58 \\
\hline
\end{tabular}

*Own development 
The students generally confirmed the positive impact of digital pedagogical tools on the acquisition and development of key competencies necessary for further professional activity $(71.58 \%)$. Having completed an online course on the Khan Academy platform focused on the applied interaction with advanced software in the field of fire safety, students identified skills that should be developed and consolidated, namely: teamwork skills and the ability to work in multidisciplinary teams (82\%), the ability to manage projects (management, planning, scheduling, budgeting, etc.) $(97 \%)$; the ability to define, formulate and solve engineering problems (91\%); the ability to effectively prioritize $(79 \%)$; striving for lifelong learning (93\%); willingness to take a calculated risk (75\%); ability to make professional decisions (83\%); self-regulation and self-motivation (90\%). However, the development of important engineering competencies such as high ethical standards, honesty and global social, intellectual and technological responsibility; good communication skills, high emotional intelligence and cognitive flexibility; entrepreneurial spirit and customer focus requires educators to search for different pedagogical methods and practices. In this regard, it can be concluded that an effective combination of traditional classroom and virtual interactions can create a complex paradigm of high-quality engineering and technical education that is competitive in the market environment.

The effectiveness of teaching and learning processes in the engineering education determined by practical exercises, experiments and laboratory exercises. Lectures and seminars are important, but they only support students in the learning process, giving them the opportunity to mentor the lecturer in obtaining the necessary subject knowledge. However, despite knowledge, technical skills are critical for engineers, according to the learning-by-doing paradigm. Therefore, engineering students need access to laboratories, technical equipment and instruments to conduct hands-on experiments, collaborate with each other, and acquire both technical and social skills related to their technical field [36].

\section{Discussion}

Recently, there have been significant technological transformations in the engineering industry that enrich educational programs [2]. Currently, vocational training requires rethinking of the structure and design of the learning environment and placing a particular emphasis on technology and self-regulated learning. MOOCs are considered a promising alternative and a complement to corporate or university learning having a number of potential benefits such as scalability, flexibility, and adaptability to specific student needs [37].

Technology has led to tectonic shifts for information available to both students and faculty, and in the way, people work together. Researchers in engineering education need better understanding the contradictions between technology and the underlying educational processes and systems that shape engineering workforce. Since technologies are widely used in education, it is advisable to divide them into manageable categories, such as: 1) innovation in teaching, specially developed around teaching design, contributing to deep thinking and meaningful learning; 2) computing tools used in 
engineering practice; 3 ) the intersection of educational and specialized professional technologies. From this perspective, it is useful to determine how technology fits into the culture of engineering programs and the culture of higher education in order to facilitate systemic change towards more effective learning [38].

The engineering industry needs an integrated education system due to its design nature. Virtual platforms, discussion forums and educational games have contributed to creativity, learning and risk-taking among engineering students. Turkish studies have examined the advantages and disadvantages of using software in architecture and engineering education [2]. The advantages of technological solutions in engineering pedagogy included the creation of alternative design projects, simple storage and sharing, easier communication with other professionals, ease of changes, faster design stages, 3D visualization, time-saving features, deeper design knowledge, evaluation, and ease of copying. The disadvantages included better visual effects instead of better design, weaker interaction between students and teachers, poor design, negative impact of programs on creativity, and professional dependence on technology [39].

Elements of MOOCs are also used by students majoring in human sciences. For instance, Moscow City Pedagogical University already gives classes in this format with the help of the Microsoft Teams platform. This allows students to work and learn at their own pace as well as enables teachers to apply flipped classroom strategies successfully.

Massive open online courses are gradually being accepted by formal education providers who are striving to better respond to the needs of their students. MOOCs help educational institutions increase the profile and the number of potential students. In recent years, there has been a significant increase in the use of massive open online courses (MOOCs) by higher educational institutions. MOOCs offer accessible course materials (text or video) with computer-generated quiz-like notes, badges and graduation certificates designed and marketed on websites such as Udacity, edX, Coursera, and FutureLearn [40]. It is believed that Massive Open Online Courses (MOOCs) have the potential to expand engineering education. According to numerous studies, the quality of MOOCs is highly dependent on interactivity and collaboration. Typically, MOOCs are rated by accessibility and usability. But, in order to develop the skills that an engineering student needs, MOOCs must foster interactivity and collaboration in their platform design [41]. For example, gamification shows significant potential in the MOOCs learning environment. Although gamification in education is "a serious approach to accelerating the learning process, teaching complex subjects and systems of thought" [42], the inclusion of a social dimension in this type of learning is essential for its integration into the MOOCs learning process. This social aspect of learning takes into account that the learning process involves other people in all situations or contexts. The inclusion of virtual communities via social media and external gamification applications (contests and receiving additional badges) is a new contribution that motivates students to pursue an engineering degree on MOOC platforms. The results of a survey conducted at the Technical University of Madrid (Spain) showed that the majority of students have a positive attitude towards gamification and the use of social media in education, especially on MOOC platforms. Gamification tools help students deepen their learning, engage in educational practice and increase learning 
motivation [43]. Another study on the effectiveness of distance pedagogy methods in engineering education was carried out in Brazil. There were 471 students participating in the study of the impact of the virtual laboratory on higher engineering education; almost half of them studied engineering disciplines. The survey showed that the virtual lab was more useful in basic courses than in advanced ones. According to students, the greatest advantage of the virtual laboratory was its accessibility at any time and in any place, which allowed them to study at their own pace. Another interesting point is that the educational process participants, who were inspired by the virtual style of educational interaction, were students with great learning needs [44]. Web 2.0 tools make communication between students and teachers synchronous and promote collaboration. Virtual labs are flexible and easy to use - they allow achieving the same cognitive results as real labs while saving resources and time. Online tools help teachers and students access knowledge easily and effectively and promote digital literacy; finally, online games encourage and motivate learners by helping them acquire professional knowledge and skills while playing [45].

However, a number of researchers are skeptical about the possibilities of MOOCs and express concern about the introduction of massive online courses in engineering education from the perspective of pedagogy [46], accessibility [47], and usability [48]. However, a set of analytical methodologies is essentially focused on the macrolevel of the learning community of the course and is less suitable for understanding a small audience of users [7]. The success of learners in online learning environments is usually measured by analyzing and interpreting quantitative indicators of online interactions. However, the usefulness of these learning proxies has been questioned as they do not necessarily reflect critical thinking — an important component of collaborative learning. Research shows that pedagogical content analysis schemes are valuable for measuring critical discourse in small formal online learning environments [49]. The integration of MOOCs into a traditional curriculum requires fine-tuning of learning outcomes, assessment methods, and student workload. Particular attention should be paid to the workload of students taking into account their prior knowledge and possible language and digital barriers [9].

\section{Conclusion}

The study demonstrates the possibilities of using massive open online courses in engineering education. In order to study the impact of digital learning formats on the acquisition of key engineering competencies by students, an educational experiment was carried out; it was performed as part of the study of the Fire Safety discipline on the basis of the online educational platform Khan Academy. Conceptually, the educational process was aimed at studying the capabilities of software in the field of fire safety, namely: PyroSim, Pathfinder, FireRisk, FIM, FireCategories, PromRisk, FireDistance, as well as gaining professional competencies in the process of performing practical tasks. The course complimented the Fire Safety curriculum emphasizing practical independent work of students. The educational experiment involved thirdyear intramural and extramural students of Moscow City Pedagogical University and 
The Saint-Petersburg University of the State Fire Service of the EMERCOM of Russia.

The online educational course was conducted with an emphasis on consolidation and acquisition of professional engineering knowledge and skills in the development of fire safety projects under simulated risk conditions using modern software and an innovative educational platform.

In the context of the educational experiment, the key competencies that $21 \mathrm{st}-$ century engineers should possess have been defined, namely:

- Basic knowledge of technical, engineering and social sciences

- High ethical standards, honesty, and global social, intellectual and technological responsibility

- Teamwork skills and the ability to work in multidisciplinary teams

- Ability to manage projects (management, planning, scheduling, budgeting, etc.)

- Ability to define, formulate and solve engineering problems

- Ability to effectively prioritize

- Good communication skills, high emotional intelligence and cognitive flexibility

- Entrepreneurial spirit and customer focus

- Striving for lifelong learning

- Readiness to take a calculated risk

- Ability to make professional decisions

- Self-regulation and self-motivation

The students generally confirmed the positive impact of digital pedagogical tools on the acquisition and development of key competencies necessary for further professional activity. Having completed an online course on the Khan Academy platform focused on the applied interaction with advanced software in the field of fire safety, students identified skills that should be developed and consolidated, namely: teamwork skills and the ability to work in multidisciplinary teams, the ability to manage projects (management, planning, scheduling, budgeting, etc.); the ability to define, formulate and solve engineering problems; the ability to effectively prioritize; striving for lifelong learning; willingness to take a calculated risk; ability to make professional decisions. However, the development of important engineering competencies such as high ethical standards, honesty and global social, intellectual and technological responsibility; good communication skills, high emotional intelligence and cognitive flexibility; entrepreneurial spirit and customer focus requires educators to search for different pedagogical methods and practices. In this regard, it can be concluded that an effective combination of traditional classroom and virtual interactions can create a complex paradigm of high-quality engineering and technical education that is competitive in the market environment.

In general, the article provides valuable results that will be useful to developers of educational programs for engineering specialties, demonstrating the pedagogical vectors of effective personnel development in demand in the modern digital market. 


\subsection{Research limitations}

The research sample consisted of 125 students; thus, the small number of participants did not allow us to identify the patterns of the influence of digital tools on the effectiveness of innovative educational practices. However, the participants demonstrated a high level of involvement, initiative and professional aspirations in the learning process. The assessment of the impact of digital learning formats on the acquisition of key engineering competencies was subjective, but it revealed pedagogical approaches to the qualitative development of engineering personnel.

\section{$7 \quad$ References}

[1] Papadakis, S., Kalogiannakis, M., Sifaki, E., Vidakis, N. (2017). Access moodle using smart mobile phones. A case study in a Greek University. In Interactivity, Game Creation, Design, Learning, and Innovation. Springer, Cham, pp. 376-385. https://doi.org/10.1007/ 978-3-319-76908-0 36

[2] Bayhan, N.G., Karaca, E. (2020). Technological innovation in architecture and engineering education - an investigation on three generations from Turkey, International Journal of Educational Technology in Higher Education, 17(1): 1-22. https://doi.org/10.1186/s41239$\underline{020-00207-0}$

[3] Bandaya, M.T, Ahmedb, M., Janc, T.R. (2014). Applications of e-Learning in engineering education: A case study, Social and Behavioral Sciences, 123: 406-413.

[4] Abed, E.K. (2019). Electronic Learning and its Benefits in Education. EURASIA Journal of Mathematics, Science and Technology Education, 15(3): em1672. https://doi.org/10.29333/ejmste/102668

[5] Mousavi, A., Mohammadi, A., Mojtahedzadeh, R., Shirazi, M., Rashidi, H. (2020). ELearning Educational Atmosphere Measure (EEAM): A New Instrument for Assessing EStudents' Perception of Educational Environment. Research in Learning Technology, 28: 2308. https://doi.org/10.25304/rlt.v28.2308

[6] Kaplan, A.M., Haenlein, M. (2016). Higher education and the digital revolution: About MOOCs, SPOCs, social media, and the cookie monster. Business Horizons, 59(4): 441450. https://doi.org/10.1016/j.bushor.2016.03.008

[7] Wang, K., Zhu, C. (2019). MOOC-based flipped learning in higher education: students' participation, experience and learning performance. International Journal of Educational Technology in Higher Education, 16(1): 33. https://doi.org/10.1186/s41239-019-0163-0

[8] Mohebi, L. (2019). MOOCs at the crossroads: A literature review and reflection drawing upon discourse analysis. Preprints, 2019: https://doi.org/10.20944/preprints201909.0211. $\underline{\mathrm{v}}$

[9] Bralić, A., Divjak, B. (2018). Integrating MOOCs in traditionally taught courses: achieving learning outcomes with blended learning, International Journal of Educational Technology in Higher Education, 15(1): 2. https://doi.org/10.1186/s41239-017-0085-7

[10] Morris, N.P. (2014). How Digital Technologies, Blended Learning and MOOCs Will Impact the Future of Higher Education. International Association for the Development of the Information Society.

[11] Brindley, J. (2014). Learner support in online distance education: Essential and evolving. In O. Zawacki-Richter, \& T. Anderson (Eds.), Online distance education: Towards a research agenda. AU Press, Athabasca University, Edmonton, pp. 287-310. https://doi.org /10.15215/aupress/9781927356623.01 
[12] Rauf, A.S., Daud, M.F., Haruzuan, M.N., Said, B.M. (2016). MOOCs in Engineering Education -A Literature Review, Regional Conference in Engineering Education. RHEd/APCETE/REES 2016, pp. 1-7.

[13] Fidalgo-Blanco, A., Sein-Echaluce, M.L., Garc1'aPealvo, F.J., Esteban Escano, J. (2014). Improving the MOOC learning outcomes throughout informal learning activities. In Proceedings of the Second International Conference on Technological Ecosystems for Enhancing Multiculturality (TEEM'14), Salamanca (Spain), pp. 611-617. https://doi.org/10. $\underline{1145 / 2669711.2669963}$

[14] Viegas, C., Marques, M., Alves, G., Galanis, N., Garcia-Peñalvo, F. (2013). Managing informal learning in engineering contexts: The learners' perspective. In 2013 1st International Conference of the Portuguese Society for Engineering Education (CISPEE). IEEE, pp. 1-6. https://doi.org/10.1109/cispee.2013.6701982

[15] Muyinda, P.B., Mayende, G., Kizito, J. (2015). Requirements for a seamless collaborative and cooperative MLearning system. In Seamless learning in the age of mobile connectivity. Springer, Singapore, pp. 201-222. https://doi.org/10.1007/978-981-287-113-8 11

[16] Ayala, G., Castillo, S. (2008). Towards computational models for mobile learning objects. In Fifth IEEE International Conference on Wireless, Mobile, and Ubiquitous Technology in Education (wmute 2008). IEEE, pp. 153-157.https://doi.org/10. 1109/wmute.2008.15

[17] Mayende, G., Prinz, A., Isabwe, C.M., Muyinda, P.B. (2017). Learning Groups in MOOCs: Lessons for Online Learning in Higher Education. International journal of Engineering Pedagogy, 7(2): 109-124. https://doi.org/10.3991/ijep.v7i2.6925

[18] Mayende, G., Isabwe, G.M.N., Muyinda, P.B., Prinz, A. (2015). Peer assessment-based assignment to enhance interactions in online learning groups. In 2015 International Conference on Interactive Collaborative Learning (ICL). IEEE, pp. 668-672. https://doi.org/10. $\underline{1109 / \text { icl.2015.7318106 }}$

[19] Nurhudatiana, A., Caesarion, A. S. (2020). Exploring User Experience of Massive Open Online Courses (MOOCs) A Case Study of Millennial Learners in Jakarta, Indonesia. In Proceedings of the 2020 9th International Conference on Educational and Information Technology, pp. 44-49. https://doi.org/10.1145/3383923.3383968

[20] Ruipérez-Valiente, J.A., Martin, S., Reich, J., Castro, M. (2020). The UnMOOCing Process: Extending the Impact of MOOC Educational Resources as OERs. Sustainability, 12(18): 7346. https://doi.org/10.3390/su12187346

[21] Bit Degree (n.d.). Comparison Overview. https://www.bitdegree.org/online-learningplatforms

[22] Mordor Intelligence. (2019). Massive Open Online Course (MOOC) Market - Growth, Trends, and Forecast (2020-2025). https://www.mordorintelligence.com/industryreports/massive-open-online-course-mooc-market. https://doi.org/10.21742/apjcri.2019.09. $\underline{11}$

[23] Technavio. (2018). E-learning Market in the US 2018-2022. https://www.technavio.com/report/e-learning-market-in-the-us-analysis-share-2018?pk_v $\mathrm{id}=2 \mathrm{a} 69 \mathrm{e} 1 \mathrm{dd} 3 \mathrm{fbc} 7 \mathrm{~b} 381591262233 \mathrm{ffe} 154$

[24] Palvia, S., Aeron, P., Gupta, P., Mahapatra, D., Parida, R., Rosner, R., Sindhi, S. (2018). Online Education: Worldwide Status, Challenges, Trends, and Implications. Journal of Global Information Technology Management, 21(4): 233-241. https://doi.org/10.1080/10 97198x.2018.1542262

[25] Duffin, E. (2019). Opinions of online college students on quality of online education U.S.https://www.statista.com/statistics/956123/opinions-online-college-students-qualityonline-education/ 
[26] Stratistics Market Research Consulting Pvt Ltd. (2019). Corporate E-Learning - Global Market Outlook (2017-2026). https://www.researchandmarkets.com/reports/4827704/co rporate-e-learning-global-market-outlook?utm source=BW\&utm medium=PressRelease \&utm code $=$ rld2 $\mathrm{dh} \&$ utm campaign $=1303824+-+$ Global + Corporate $+\mathrm{E}-$ Learning + Market + Value + Nears $+\% 2450+$ Billion + by $+2026 \&$ utm exec $=$ joca220prd. https://doi.org/10.3403/30383262

[27] Gaebel, M. (2015). E-learning in the European Higher Education Area. https://enqa.eu/wpcontent/uploads/2015/12/E-learning-in-the-European-Higher-Education-Area Gaebel.pdf

[28] Guide 2 Research (2020). Online Education Statistics: 2020 Data on Higher Learning \& Corporate Training. http://www.guide2research.com/research/online-education-statistics

[29] Gao, X., Li, P., Shen, J., Sun, H. (2020). Reviewing assessment of student learning in interdisciplinary STEM education. International Journal of STEM Education, 7: 24. https://doi.org/10.1186/s40594-020-00225-4

[30] Lin, K., Wu, Y., Hsu., Y., Williams, J. (2021). Effects of infusing the engineering design process into STEM project-based learning to develop preservice technology teachers' engineering design thinking. International Journal of STEM Education, 8: 1. https://doi.org/10.1186/s40594-020-00258-9

[31] FireCat (2020). Fire safety calculation software. https://pyrosim.ru/

[32] Khan Academy (2020). Our mission is to provide a free, world-class education for anyone, anywhere. https://www.khanacademy.org/about

[33] Das, S., Pistrui, D. (2020). Reimagining Engineering Education: Does Industry 4.0 need Education 4.0? In 2020 ASEE Virtual Annual Conference Content Access. https://doi.org/10.18260/1-2--35136

[34] World Economic Forum (2015). New Vision for Education Unlocking the Potential of Technology. British Columbia Teachers' Federation, Vancouver, BC.

[35] American Society for Engineering Education (2017). Transforming Undergraduate Education in Engineering Phase II: Insights from Tomorrow's Engineers. Workshop Report. Washington, DC.

[36] Ozadowicz, A. (2020). Modified Blended Learning in Engineering Higher Education during the COVID-19 Lockdown-Building Automation Courses Case Study. Education Sciences, 10(10): 292. https://doi.org/10.3390/educsci10100292

[37] Egloffstein, M., Ifenthaler, D. (2017). Employee perspectives on MOOCs for workplace learning. TechTrends, 61(1): 65-70. https://doi.org/10.1007/s11528-016-0127-3

[38] Koretsky, M. (2019). Using Technology to Enhance Learning and Engagement in Engineering, Advances in Engineering Education. https://files.eric.ed.gov/fulltext/EJ122029 $\underline{6 . p d f}$

[39] Guney, D. (2015). The importance of computer-aided courses in architectural education. Procedia-Social and Behavioral Sciences, 176: 757-765. https://doi.org/10.1016/j.sbspro. $\underline{2015.01 .537}$

[40] Ubachs, G., Konings, L., Nijsten, B. (2019). The 2019 OpenupEd trend report on MOOCs. https://openuped.eu/images/Publications/The 2019 OpenupEd Trend Report on MOOC s.pdf. https://doi.org/10.4324/9781315751108-16

[41] Gamage, G., Perera, I., Fernando, S. (2020). MOOCs Lack Interactivity and Collaborativeness: Evaluating MOOC Platforms. International journal of Engineering Pedagogy, 10(2): 94-111. https://doi.org/10.3991/ijep.v10i2.11886

[42] Kapp, K.M. (2012). The gamification of learning and instruction: game-based methods and strategies for training and education. John Wiley \& Sons. 
[43] Borras-Gene, O., Martinez-Nu'nez, M., Fidalgo-Blanco, A. (2016). New Challenges for the Motivation and Learning in Engineering Education Using Gamification in MOOC. International Journal of Engineering Education, 32(1): 501-512.

[44] Viegas, C., Pavani, A., Lima, N., Marques, A., Pozzo, I., Dobboletta, E., Atencia, V., Barreto, D., Calliari, F., Fidalgo, A., Lima, D., Temporão, G., Alvesa, G. (2018). Impact of a remote lab on teaching practices and student learning. Computers \& Education, 126: 201216. https://doi.org/10.1016/j.compedu.2018.07.012

[45] Kefalis, C., Drigas, A. (2019). Web Based and Online Applications in STEM Education, International journal of Engineering Pedagogy, 9(4): 76-85. https://doi.org/10.3991/ ijep.v9i4.10691

[46] Swan, K., Day, S., Bogle, L. (2016). Metaphors for learning and MOOC pedagogies. In Proceedings of the Third (2016) ACM Conference on Learning@ Scale, pp. 125-128. https://doi.org/10.1145/2876034.2893385

[47] Ramírez-Vega, A., Iniesto, F., Rodrigo, C. (2017). Raising awareness of the accessibility challenges in mathematics moocs. In Proceedings of the 5th International Conference on Technological Ecosystems for Enhancing Multiculturality, pp. 1-8. https://doi.org/10.1145/ $\underline{3144826.3145435}$

[48] Yousef, A.M.F., Chatti, M.A., Schroeder, U., Wosnitza, M. (2015). A usability evaluation of a blended MOOC environment: An experimental case study. International Review of Research in Open and Distributed Learning, 16(2): 69-93. https://doi.org/10.19173/ irrodl.v16i2.2032

[49] O'Riordan, T., Millard, D.E., Schulz, J. (2020). Is critical thinking happening? Testing content analysis schemes applied to MOOC discussion forums. Computer Applications in Engineering Education, in press. https://doi.org/10.1002/cae.22314

\section{Authors Information}

Zotova Marina Victorovna is a Candidate of Pedagogical Sciences, Associate Professor at the Department of Special Psychology and Psychological and Social Technologies in Moscow City Pedagogical University, Moscow, Russia. Email: m.v.zotova2015@yandex.ru.

Likhouzova Tetiana Anatoliivna - PhD, Associate Professor at the Department of Technical Cybernetics in National Technical University of Ukraine "Igor Sikorsky Kyiv Polytechnic Institute", Kyiv, Ukraine. Email: likhouzovatet55@,rambler.ru., tetiana.lik@gmail.com

Shegai Liliya Avrorovna is a senior teacher at Academic English Language Department in Far Eastern Federal University, Artem, Russia. Email: shegaililiya@mail.ru.

Korobeynikova Elena Germanovna is a $\mathrm{PhD}$ in Chemistry, Assistant Professor at the Department of Physical and Chemical Principles of Combustion and Fire Suppression in Saint-Petersburg University of State Fire Service of EMERCOM of Russia, Saint Petersburg. Email: korhelen2012@gmai.com.

Article submitted 2020-12-09. Resubmitted 2021-03-15. Final acceptance 2021-03-15. Final version published as submitted by the authors. 